\title{
Peramalan Jumlah Kasus Penyakit Hipertensi Di Kabupaten Jember Dengan Metode Time Series
}

\section{Forecasting of Hypertension Cases In Jember Regency With Time Series Method}

\author{
Nanda Galib Putri ${ }^{*}$, Yennike Tri Herawati ${ }^{1}$, Andrei Ramani1 \\ 1) Fakultas Kesehatan Masyarakat, Universitas Jember \\ nandaagalibputri@gmail.com $^{1}$ \\ DOI: http://doi.org/10.29080/jhsp.v3i1.161
}

\section{Kata Kunci}

Hipertensi

Peramalan

Deret Waktu

\section{Keywords}

Hypertension

Forecasting

Time sries

\begin{abstract}
Abstrak
WHO menyebutkan bahwa persentase akibat penyakit tidak menular lebih besar dibandingkan penyakit penular. Tren kematian akibat Penyakit Tidak Menular di Indonesia mengalami peningkatan setiap tahunnya. Tujuan penelitian adalah peramalan terkait jumlah kasus penyakit hipertensi di Kabupaten Jember sebagai bahan pertimbangan dalam pengambilan keputusan terkait perencanaan pengembangan maupun perbaikan strategi pengendalian penyakit hipertensi. Metode peramalan menggunakan metode time series dibantu oleh aplikasi POM-QM. Hasil penelitian menunjukkan kemungkinan kasus hipertensi untuk 36 bulan yang akan datang memiliki pola yang sama dengan data actual. Nilai MAPE untuk kasus hipertensi pada laki-laki adalah 25,71\% ; pada perempuan adalah 19,63\%; pada usia $\leq 44$ tahun 98,42\%; dan usia $\geq 45$ tahun adalah $13,98 \%$. Kesimpulan penelitian adalah kasus hipertensi di masa yang akan datang kemungkinan memiliki kemiripan kasus dengan pola data aktual Rekomendasi penelitian adalah metode peramalan dapat digunakan sebagai alternatif untuk membantu mengambil keputusan terkait kasus hipertensi. Selain itu, dapat dilakukan penghitungan health expenditure dari kasus hipertensi untuk dapat memperkirakan kemungkinan biaya yang dibutuhkan kasus hipertensi di masa yang akan datang perencanaan strategi untuk meningkatkan keberhasilan baik program, kegiatan maupun anggaran untuk mengendalikan kasus hipertensi di Kabupaten Jember.
\end{abstract}

\begin{abstract}
WHO said that Non Communicable Disease have a higher percentage than Communicable Disease (NCD). NCD's deaths trend in Indonesia has increased each year. The goal of this research is forecasting the number of hypertension cases in Jember Regency for consideration in decision making planning related development or repair existing strategies to control hypertension. Method of forecasting using time series and aided by application of POM-QM. The results showed that hypertension's case for 36 months later have similar pattern with actual data. The value of the MAPE for the hypertension's case in men is 25.71\%; on women was 19.63\%; at the age of 44 years $\leq 98.42 \%$; and age $\geq 45$ years was $13.98 \%$. Conclusion of the research was the case of hypertension in the future possibility of case has similarities with the patterns of actual data. The research recommendation is forecasting method can be used as an alternative to help decisions making of hypertension. In addition, health expenditure calculation can be made of the cases of hypertension to be able to estimate the likely costs of needed cases of hypertension in the future
\end{abstract}

\section{Pendahuluan}

PTM menjadi isu penting karena perlunya dukungan dalam pencegahan dan pengendalian PTM serta faktor risikonya dalam upaya mendorong perubahan perilaku masyarakat untuk hidup sehat. Data WHO menyebutkan bahwa persentase kematian akibat PTM sebesar 63\% dibandingkan dengan penyakit 
menular. Tren kematian akibat PTM di Indonesia meningkat dari 37\% di tahun 1990 menjadi 57\% di tahun 2015.Hipertensi merupakan salah satu penyakit tidak menular dengan kasus terbanyak. Menurut American Heart Association, penduduk Amerika dengan usia diatas 20 tahun yang menderita hipertensi mencapai angka 74,5 juta jiwa, namun hampir sekitar 90-95\% kasus tidak diketahui penyebabnya. Kasus hipertensi diperkirakan akan meningkat di negara berkembang pada 2025 salah satunya Indonesia. Peningkatan tersebut akan menjadi $80 \%$ atau 1,15 miliar kasus dari 693 juta kasus pada tahun 2000. Prediksi tersebut berdasarkan angka penderita hipertensi dan pertambahan jumlah penduduk. Selama periode 2011-2025, cumulative lost output di negara berpenghasilan rendah dan menengah terkait dengan penyakit tidak menular diproyeksikan sebesar US\$ 7,28 triliun. Kerugian tahunan sekitar US\$ 500 milyar untuk penyakit tidak menular serta sekitar $4 \%$ dari pendapatan produk domestik bruto di negara berpenghasilan rendah dan menengah. Penyakit kardiovaskular termasuk hipertensi menyumbang hampir setengah dari biaya yang dikeluarkan tersebut (1-3).

Berdasarkan hasil RISKESDAS 2018, prevalensi hipertensi berdasarkan diagnosis tenaga kesehatan dan hasil pengukuran terlihat meningkat dengan bertambahnya umur. Prevalensi hipertensi dengan usia lebih dari sama dengan 18 tahun adalah 34,1\%. Prevalensi tersebut meningkat dari tahun 2013 dengan persentase $25,8 \%$. Berdasarkan pengukuran tekanan darah, hipertensi lebih banyak menyerang jenis kelamin perempuan $(28,8 \%)$ daripada laki-laki $(22,8 \%)$. Prevalensi hipertensi dengan usia lebih dari sama dengan 18 tahun di Provinsi Jawa Timur adalah 21,5\% berdasarkan hasil wawancara dan 26,2\% untuk hasil pengukuran tekanan darah (4)

Berdasarkan data dari Dinas Kesehatan Kabupaten Jember tahun 2018, jumlah kasus penyakit hipertensi dari tahun 2014 - 2017 memiliki jumlah kasus terbanyak pada penyakit tidak menular dan menjadi prioritas utama untuk ditangani. Data penyakit hipertensi memiliki jumlah 22.185 kasus pada 2014 kemudian meningkat menjadi 29.683 kasus di tahun 2015. Penurunan menjadi 28.403 kasus pada tahun 2016 dan meningkat kembali menjadi 30.511 kasus pada 2017. Pada tahun 2017, jumlah kasus hipertensi yang terjadi pada perempuan adalah $53,69 \%$ atau 16.385 kasus. Pada laki-laki adalah $46,31 \%$ atau 14.135 kasus. Komplikasi dari hipertensi yang tidak tertangani dapat menyebabkan penyakit katastropik.

Besarnya kasus penyakit berdampak terhadap besarnya biaya kesehatan suatu penyakit sehingga akan menimbulkan masalah apabila tidak tertangani. Keadaan tersebut tentunya memerlukan perbaikan strategi maupun pengembangan strategi dalam menyelesaikan kasus hipertensi. Pengembangan maupun perbaikan strategi merupakan bagian dari perencanaan strategis suatu organisasi. Perencanaan strategis dibuat untuk mengantisipasi tren di masa yang akan datang menggunakan data dan asumsi. Perencanaan keuangan penting dilakukan dalam menghadapi kebutuhan dan keinginan yang tidak pasti. Pengalokasian dana dan perencanaan baik secara lisan, tulisan, ataupun ide baiknya dilakukan sebelum melakukan pembelian agar keuangan dapat teratur dengan baik tanpa ada kerugian finansial baik dalam jangka pendek, menengah, ataupun dalam jangka panjang. Salah satu langkah yang dapat diambil untuk menganalisis keadaan di masa yang akan datang menggunakan teknik peramalan (forecasting). Peramalan (forecasting) merupakan suatu proses untuk memperkirakan kebutuhan di masa datang yang meliputi kebutuhan dalam ukuran kuantitas, kualitas, waktu dan lokasi yang dibutuhkan dalam rangka memenuhi permintaan barang atau jasa berdasarkan data histori yang ada (5-7).

Peramalan terkait jumlah kasus penyakit hipertensi di Kabupaten Jember dibutuhkan sebagai bahan pertimbangan dalam pengambilan keputusan terkait perencanaan pengembangan maupun perbaikan strategi yang telah ada sehingga masalah penyakit hipertensi dapat berkurang.

\section{Metode Penelitian}

Jenis penelitian adalah penelitian deskriptif dengan pendekatan kuantitatif yang menggambarkan situasi atau kejadian sehingga metode ini berkehendak mengadakan akumulasi data dengan tujuan untuk mendekripsikan situasi atau kejadian secara tepat dan akurat, bukan untuk mencari hubungan sebab akibat. Sumber data berasal dari data sekunder kasus hipertensi yang didapatkan di bagian Pencegahan dan Penanganan Penyakit Tidak Menular Dinas Kesehatan Kabupaten Jember. Pengumpulan data menggunakan Microsoft Excel. Peramalan dilakukan dengan metode time series dengan model exponential smoothing. Peramalan dilakukan dengan bantuan aplikasi POM-QM.

\section{Hasil Penelitian \\ Peramalan Kasus Hipertensi Di Kabupaten Jember Tahun 2018 - 2021}

Data penelitian adalah jumlah kasus baru hipertensi selama 36 bulan terakhir atau data dari bulan Juli 2015 hingga Juni 2018 Kasus hipertensi di Kabupaten Jember berdasarkan jenis kelamin dari bulan Juli 2015 hingga Juni 2018 adalah 108.050 kasus baru, yaitu 45.624 kasus (42,22\%) ditemukan pada laki - laki dan 62.426 kasus $(57,78 \%)$ ditemukan pada perempuan. Sedangkan berdasarkan golongan usia, untuk usia 
$\leq 44$ tahun adalah 22.794 kasus atau 14,24\% dan untuk usia $\geq 45$ tahun adalah 137.300 kasus atau 85,76\%.

Pola kasus hipertensi pada laki - laki pada usia $\leq 44$ tahun dan usia $\geq 45$ tahun memiliki kecenderungan memiliki tren meningkat dan tidak stabil. Grafik kasus baru hipertensi pada perempuan pada usia $\leq 44$ tahun dan usia $\geq 45$ tahun menunjukkan tren pola stabil meskipun terdapat peningkatan yang cukup banyak pada waktu tertentu. Kasus hipertensi pada laki-laki maupun perempuan pada usia $\leq 44$ tahun dan usia $\geq 45$ tahun memiliki kecenderungan menurun pada bulan Juni dan September 2018 .

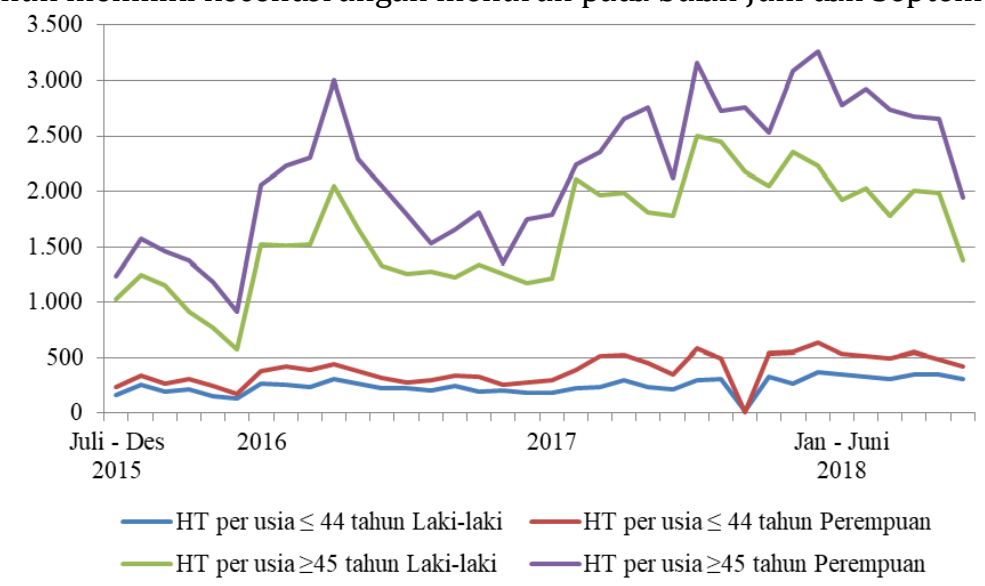

Grafik 4.1 Pola kasus hipertensi berdasarkan golongan jenis kelamin dan usia di Kabupaten Jember Juli 2015 - Juni 2018.

Data hipertensi yang telah dikumpulkan dalam Microsoft excel ke aplikasi POM-QM dan menentukan model peramalan yang digunakan. Pada peramalan ini menggunakan model peramalan exponential smoothing dengan $\alpha$ untuk kasus pada laki-laki adalah 0,47 dan perempuan adalah 0,30 sedangkan penggunaan $\alpha$ untuk golongan usia untuk usia $\leq 44$ tahun adalah 0,3 dan usia $\geq 45$ tahun adalah 0,99 . Nilai MAPE untuk kasus hipertensi pada laki-laki adalah 25,71\%; perempuan adalah 19,63\%; pada usia $\leq 44$ tahun 98,42\%; dan usia $\geq 45$ tahun adalah $13,98 \%$.

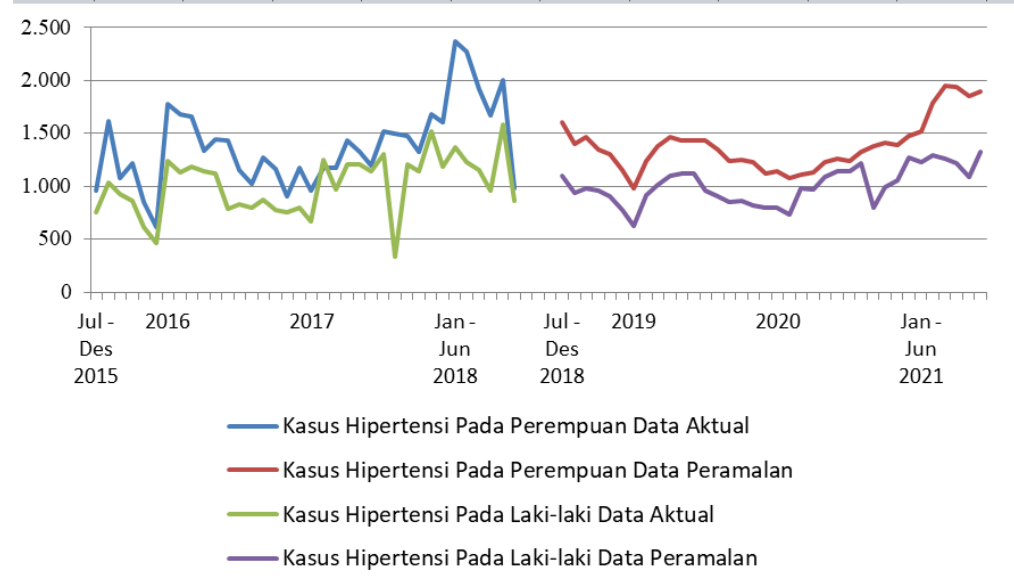

Grafik 4.2 Pola kasus hipertensi berdasarkan golongan jenis kelamin di Kabupaten Jember Juli 2015 - Juni 2018

Di Kabupaten Jember, kasus hipertensi diiringi dengan bertambahnya usia, jumlah kasus hipertensi di Kabupaten Jember semakin meningkat pada golongan usia $\geq 45$ tahun. Pada peramalan kasus hipertensi untuk usia $\leq 44$ tahun menggunakan $\alpha$ yaitu 0,3 sedangkan pada usia $\geq 45$ tahun menggunakan $\alpha$ yaitu 0,99 . Penggunaan golongan usia $\leq 44$ tahun dan $\geq 45$ tahun disebabkan untuk melihat pergerakan pola data berdasarkan usia sebelum dan sesudah menopause. Pada grafik dapat dilihat kasus hipertensi golongan usia $\leq 44$ tahun memiliki jumlah kasus yang lebih sedikit dibandingkan dengan golongan usia $\geq 45$ tahun namun memiliki tren yang meningkat. Pada kasus hipertensi golongan usia $\geq 45$ tahun kecenderungan perubahan data tidak beraturan namun memiliki tren yang cenderung meningkat. 


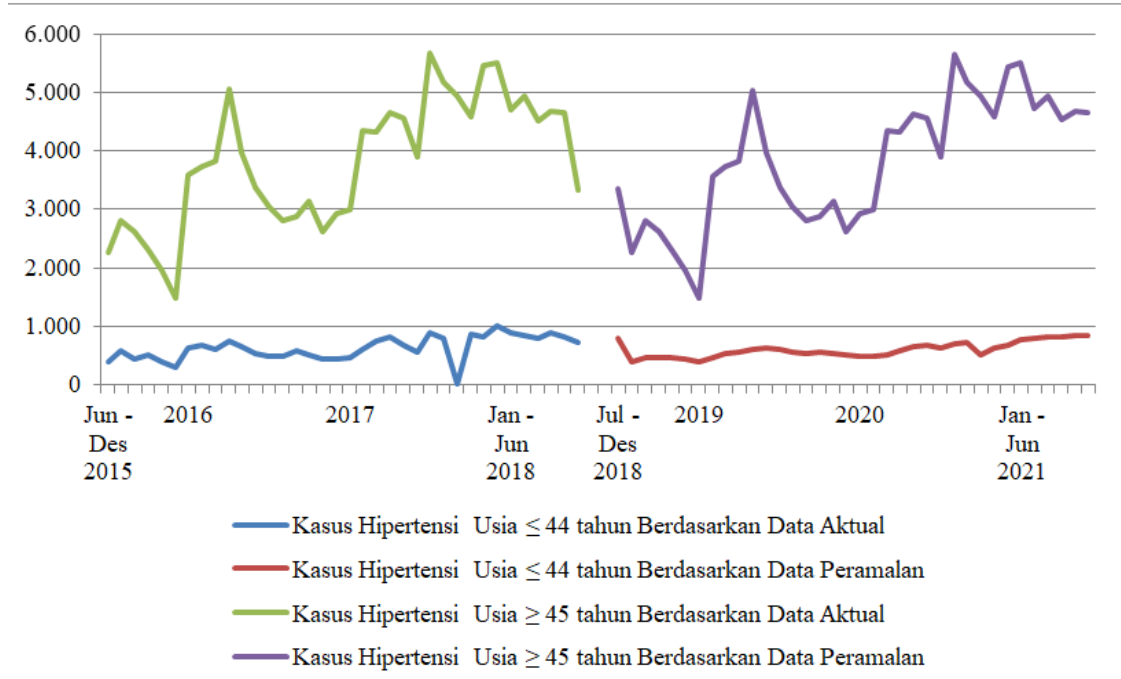

Grafik 4.3 Hasil Peramalan Kasus Hipertensi Berdasarkan Golongan Usia Tahun di Kabupaten Jember

Grafik peramalan kasus hipertensi pada laki - laki pada Juli 2018 hingga Juni 2021 di Kabupaten Jember cenderung memiliki kemiripan tren kasus tetapi memiliki pola yang lebih stabil. Grafik kasus hipertensi pada perempuan di Kabupaten Jember memiliki kecenderungan pola yang mirip antara data aktual dengan hasil peramalan. Perbedaannya terletak pada pola kasus di beberapa bulan tertentu yang dapat disebabkan beberapa factor dan tren meningkat di bulan selanjutnya.

\section{Pembiayaan Kasus Hipertensi}

Pembiayaan penyakit di pelayanan rawat jalan puskesmas Kabupaten Jember telah digratiskan dengan tarif awal adalah Rp. 5000,-namun telah digratiskan. Pembiayaan hipertensi di puskesmas berasal dari pemerintah, dan BPJS Kesehatan. Pembiayaan hipertensi yang berasal dari pemerintah di Dinas Kesehatan Kabupaten Jember digunakan dalam menyediakan alat kesehatan, obat - obatan, serta kegiatan yang bersifat promotif dan preventif seperti kegiatan penyuluhan dan skrining di posbindu serta kegiatan PIS-PK.

Berdasarkan studi literatur dari A Global Brief Of Hypertension: Silent Killer, Global Public Health Crisis yang diterbitkan WHO biaya pelaksanaan program hipertensi sangat rendah yaitu $\leq$ US $\$ 1$ per orang pada negara berpenghasilan rendah, $\leq$ US $\$ 1,50$ per orang pada negara berpenghasilan menengah ke bawah, dan $\geq$ US $\$ 2,50$ per orang pada negara berpenghasilan menengah ke atas. Proporsi pengeluaran untuk biaya kesehatan pelaksanaan program ini adalah $4 \%$ di negara berpenghasilan rendah, $2 \%$ di negara dengan pendapatan menengah ke bawah dan kurang dari $1 \%$ di negara berpendapatan menengah ke atas.

Pembiayaan per kasus hipertensi di Puskesmas Kabupaten Jember sulit dilakukan sehingga perkiraan pembiayaan hipertensi per kasus dilakukan menggunakan standar pembiayaan kasus hipertensi menurut WHO. Indonesia merupakan negara berpenghasilan menengah ke bawah. Pembiayaan hipertensi di Indonesia sebagai negara dengan penghasilan menengah ke bawah adalah $\leq$ US $\$ 1,50$ per orang.

\section{Pembahasan}

Pada kasus hipertensi berdasarkan jenis kelamin perempuan memiliki kategori akurasi prediksi baik sedangkan pada laki-laki memiliki kategori reasonable. Pada kasus hipertensi berdasarkan usia, untuk usia $\leq 44$ tahun memiliki akurasi prediksi rendah sedangkan pada akurasi prediksi untuk usia $\geq 45$ tahun memiliki kategori baik. Menurut Gustiriansyah, akurasi prediksi dengan nilai MAPE $\leq 10 \%$ memiliki kategori tinggi, $10-20 \%$ kategori baik, $\geq 20 \%$ kategori reasonable, dan $\geq 50 \%$ kategori rendah8. Pada penelitian didapatkan nilai MAPE untuk kasus hipertensi pada laki-laki adalah 25,71\% ; pada perempuan adalah 19,63\%; pada usia $\leq 44$ tahun $98,42 \%$; dan usia $\geq 45$ tahun adalah $13,98 \%$.

Pada tahun 2008, di seluruh dunia, sekitar $40 \%$ orang dewasa usia $\geq 25$ telah didiagnosis dengan tekanan darah tinggi. Peningkatan jumlah orang dengan hipertensi dari 600 juta pada tahun 1980 untuk 1 miliar pada tahun 2008. Peningkatkan prevalensi hipertensi dikaitkan dengan pertumbuhan penduduk, penuaan dan faktor risiko perilaku, seperti diet tidak sehat, penggunaan alkohol berbahaya, kurangnya aktivitas fisik, kelebihan berat badan dan paparan stres terus-menerus2. Data WHO tahun 2011 menunjukkan 1,1 milyar orang menderita hipertensi dan 2/3 diantaranya terdapat di negara berkembang yang berpenghasilan rendah sampai sedang. Prevalensi hipertensi diperkirakan akan terus meningkat dan 
diprediksi pada tahun 2025 sebanyak 29\% orang dewasa di dunia akan terkena hipertensi. Hipertensi menyebabkan kematian delapan juta orang pertahun dengan 1,5 juta diantaranya berada di Asia Tenggara yang sepertiga populasinya menderita hipertensi dan dapat menyebabkan meningkatnya beban biaya kesehatan(8).

Berdasarkan hasil pengukuran tekanan darah, prevalensi hipertensi pada penduduk umur 18 tahun ke atas tahun 2007 di Indonesia adalah sebesar 31,7\%. Sedangkan jika dibandingkan dengan tahun 2013 terjadi penurunan sebesar 5,9\% (dari 31,7\% menjadi 25,8\%). Penurunan ini bisa terjadi berbagai macam faktor, seperti alat pengukur tensi yang berbeda, masyarakat yang sudah mulai sadar akan bahaya penyakit hipertensi. Berdasarkan data tersebut, kasus hipertensi mulai muncul pada usia dua puluhan kemudian kemungkinannya akan semakin meningkat seiring dengan bertambahnya usia (9).

Data aktual kasus hipertensi yang diperoleh di Kabupaten Jember menunjukkan tren yang cenderung meningkat selama 36 bulan terakhir. Berdasarkan data ditemukan bahwa pada penderita hipertensi di Kabupaten Jember lebih banyak ditemukan pada perempuan daripada laki-laki. Prevalensi terjadinya hipertensi pada pria sama dengan wanita. Namun wanita terlindung dari penyakit kardiovaskuler sebelum menopause. Wanita yang belum mengalami menopause dilindungi oleh hormon estrogen yang berperan dalam meningkatkan kadar High Density Lipoprotein (HDL). Kadar kolesterol HDL yang tinggi merupakan faktor pelindung dalam mencegah terjadinya proses aterosklerosis. Pria di dalam populasi umum memiliki angka diastolik tertinggi pada tekanan darahnya dibandingkan dengan wanita pada semua usia dan juga pria memiliki angka prevalensi tertinggi untuk terjadinya hipertensi. Berdasarkan golongan usia, semakin meningkat usia maka semakin banyak kasus hipertensi yang tercatat. Hipertensi merupakan salah satu penyakit degeneratif, umumnya tekanan darah bertambah secara perlahan dengan seiring bertambahnya umur $(10,11)$.

Faktor lain ditemukannya kasus hipertensi lebih banyak adalah kunjungan masyarakat ke FKTP, adanya kegiatan yang dilaksanakan di posbindu, pusling, dan kegiatan Program Indonesia Sehat Pendekatan Keluarga yang mencatat semua kasus sakit dengan mendatangi masyarakat sehingga semakin banyak kasus hipertensi yang tercatat. Hal tersebut sebagai target dari Dinas Kesehatan untuk mencapai target standar pelayanan minimal ke 6,7,8 Peraturan Menteri Kesehatan Nomor 43 Tahun 2016 tentang Standar Pelayanan Minimal Kesehatan.

Kasus hipertensi pada bulan September 2017 baik secara penggolongan jenis kelamin maupun usia mengalami penurunan tajam akibat adanya gerakan masyarakat bersama yang dilaksanakan oleh puskesmas pada bulan Agustus 2017. Gerakan tersebut merupakan skrining serentak di puskesmas Kabupaten Jember sebagai salah satu kegiatan untuk menggunakan 30 alat kesehatan baru yang dinamakan posbindu kit. Gerakan tersebut juga membawa obat-obatan untuk pasien. Obat yang dibawa saat skrining oleh posbindu sebenarnya tidak diperbolehkan karena tidak sesuai dengan standar operasional tetapi petugas tetap membawa obat-obatan karena melihat wilayah tinggal penderita hipertensi. Akses yang sulit untuk mencapai fasilitas kesehatan dan kondisi pasien yang tidak mampu mengunjungi fasilitas kesehatan atau faktor usia lanjut atau tidak ada yang mengantarkan pasien menuju fasilitas kesehatan menjadi pertimbangan dibawanya obat-obatan oleh petugas posbindu. Pada bulan Juni 2017, baik data kasus hipertensi berdasarkan golongan usia maupun jenis kelamin memiliki penurunan kasus. Hal dimungkinan karena adanya bulan puasa ramadhan sehingga ketika pengukuran tekanan darah baik di puskesmas maupun kegiatan promosi dan preventif yang dilaksanakan menunjukkan penurunan kasus.

Pelayanan kesehatan yang dilaksanakan di FKTP untuk mengendalikan kasus hipertensi melalui kegiatan di puskesmas, posbindu, puskesmas keliling, dan Program Indonesia Sehat - Pendekatan Keluarga (PIS-PK). PIS-PK merupakan program yang memberikan pelayanan kesehatan terkait hipertensi kepada masyarakat, tidak hanya pelayanan kesehatan kuratif namun juga kegiatan promotif dan preventif berupa kegiatan penyuluhan, konseling, senam, cek tekanan darah. Salah satu sasaran PIS-PK adalah penanggulangan penyakit tidak menular13. Kegiatan dalam pencegahan dan pengendalian hipertensi yaitu 1) meningkatkan promosi kesehatan melalui KIE dalam pengendalian hipertensi dengan perilaku CERDIK; 2) self awareness (pengukuran tekanan darah secara rutin); 3)meningkatkan akses ke Fasilitas Kesehatah Tingkat Pertama (FKTP), 4) optimalisasi sistem rujukan, dan peningkatan mutu pelayanan, 5) dan pencegahan komplikasi hipertensi khususnya penyakit jantung dan pembuluh darah di FKTP menggunakan Carta Prediksi Risiko yang di adopsi dari WHO (8).

Kasus hipertensi di Kabupaten Jember kemungkinan besar mengalami peningkatan karena semakin gencarnya kegiatan untuk menemukan penderita hipertensi sebagai salah satu upaya pencapaian SPM Kesehatan terkait hipertensi sehingga membutuhkan perencanaan yang efektif untuk menurunkan kasusnya. Perencanaan tersebut memerlukan data yang dapat memperlihatkan situasi yang mungkin terjadi di masa yang akan datang, salah satu caranya dengan melalui peramalan (forecasting). Hasil peramalan dapat menjadi pertimbangan bagi organisasi dalam menentukan pengambilan keputusan terkait perencanaan yang harus dibuat dalam menangani kasus hipertensi. Peramalan memiliki dampak terhadap tiga hal, yaitu : 


\section{a. Sumber Daya Manusia}

Permintaan akan pelayanan kesehatan mempengaruhi organisasi dalam mempekerjakan, melatih atau memberhentikan pekerja. Apabila bagian SDM kurang mempersiapkan sumber daya manusia melalui pelatihan maka kualitas pekerja akan menurun.

b. Kapasitas

Saat kapasitas tidak mencukupi maka mengakibatkan tidak terjaminnya pengiriman (pelayanan), kehilangan konsumen, dan kehilangan pangsa pasar. Namun kapasitas yang berlebihan akan membuat peningkatan pada biaya. Apabila kasus hipertensi memiliki peningkatan yang tajam tanpa diimbangi dengan sumber daya yang sesuai maka kemampuan organisasi akan mengalami mengalami penurunan dalam memberikan pelayanan kesehatan yang dibutuhkan.

c. Supply Chain Management

Cakupan rantai pasokan adalah seluruh aktivitas terkait arus dan transformasi barang maupun jasa awal hingga sampai ke pengguna akhir yang mengintegrasikan proses operasi dari bahan baku, proses, hingga dapat didapatkan konsumen. Hubungan yang baik dengan pemasok serta harga barang dan komponen yang bersaing bergantung pada peramalan yang akurat (12).

\section{Pembiayaan Hipertensi Di FKTP}

Jumlah kasus hipertensi yang memiliki kecenderungan meningkat tentunya meningkatkan jumlah biaya yang dikeluarkan. Peningkatan pembiayaan kesehatan disebabkan beberapa hal, yaitu: tingkat inflasi, tingkat permintaan, kemajuan ilmu dan teknologi, perubahan pola penyakit, perubahan pola pelayanan kesehatan, perubahan pola dokter - pasien, lemahnya mekanisme pengendalian biaya, penyalahgunaan asuransi kesehatan. Pembiayaan kesehatan dilihat dari dua sudut :

a. Penyedia pelayanan kesehatan, adalah besarnya dana yang harus disediakan dalam menyelenggarakan upaya kesehatan yang menjadi persoalan pemerintah dan ataupun pihak swasta atau pihak lain yang akan menyelenggarakan upaya kesehatan. Besaran dana ini merujuk kepada seluruh biaya investasi dan biaya operasional.

b. Pemakai jasa pelayanan, yaitu besarnya dana yang perlu dipersiapkan untuk memanfaatkan pelayanan kesehatan. Persoalan ini berkaitan dengan para pemakai jasa pelayanan serta pemerintah untuk menjamin pemenuhan kebutuhan pelayanan kesehatan bagi masyarakat.

Perhitungan total biaya berdasarkan besarnya dana yang dikeluarkan oleh penyedia jasa dan pemakai jasa pelayanan kesehatan. Penghitungan biaya juga dilihat berdasarkan keuangan yang ada di pemerintah berupa subsidi sehingga penghitungan biaya yang digunakan tidak sama. Total biaya kesehatan dari sektor pemerintah tidak dihitung dari pemakai jasa layanan, tetapi berdasarkan dana yang dikeluarkan pemerintah untuk menyelenggarakan pelayanan kesehatan. Syarat pembiayaan kesehatan yaitu 1) Adanya jumlah dana yang cukup sehingga masyarakat dapat memanfaatkan pelayanan kesehatan; 2) Penyebaran dana yang sesuai kebutuhan sehingga tidak menyulitkan penyelenggaraan kesehatan; 3) Pemanfaatan yang teratur sehingga tidak akan menimbulkan kesulitan masyarakat dalam mengakses pelayanan kesehatan. Apabila syarat pembiayaan kesehatan dilakukan dengan baik maka akan adanya peningkatan efektifitas dan efisiensi dari pembiayaan kesehatan. Peningkatan efektivitas pembiayaan dapat dilakukan melalui penyebaran alokasi dana dari kegiatan yang bersifat pengobatan (kuratif) menjadi pencegahan (preventif) sedangkan peningkatan efisiensi melalui mekanisme pengawasan dan pengendalian salah satunya dengan dibuatnya standar pelayanan minimal (SPM) sehingga akan meminimalkan pembiayaan. Kegiatan lain terkait efisiensi pembiayaan melalui kerjasama antar institusi maupun antar sistem (sarana kesehatan lainnya).

Pembiayaan kesehatan di puskesmas yang berasal dari pemerintah menurut Peraturan Menteri Kesehatan Nomor 75 Tahun 2014 tentang Puskesmas, bahwa pendanaan di puskesmas berasal dari APBN, APBD, serta sumber - sumber lain yang sah dan tidak mengikat. Menurut Peraturan Menteri Kesehatan Nomor 52 Tahun 2016 tentang Standar Tarif Pelayanan Kesehatan Dalam Penyelenggaraan Program Jaminan Kesehatan, dana kapitasi merupakan besaran pembayaran per bulan yang dibayar di muka kepada FKTP berdasarkan jumlah peserta yang terdaftar tanpa memperhitungkan jenis dan jumlah pelayanan kesehatan yang diberikan. Dana non kapitasi merupakan besaran pembayaran per bulan yang dibayar di muka kepada FKTP berdasarkan jenis dan jumlah pelayanan kesehatan yang diberikan. Kegiatan promotif dan preventif berasal dari kedua pembiayaan tersebut. Dana promosi dan preventif kesehatan yang berasal dari pemerintah termasuk dalam Dana Alokasi Khusus (DAK). Menurut Peraturan Nomor 66 Tahun 2017 tentang Petunjuk Operasional Penggunaan Dana Alokasi Khusus Fisik Bidang Kesehatan Tahun Anggaran 2018 pasal 5 ayat 2 menyebutkan bahwa dana penyediaan alat kesehatan, penyediaan obat-obatan (kefarmasian), kegiatan promosi kesehatan dan sistem informasi termasuk dalam Dana Alokasi Fisik reguler. Pembiayaan klaim kegiatan promotif dan preventif terkait hipertensi yang berasal dari BPJS Kesehatan yaitu kegiatan Prolanis masuk ke dalam dana kapitasi.

Hasil peramalan dapat digunakan untuk melihat kemungkinan pembiayaan hipertensi di masa yang akan datang dan dapat menentukan pengambilan keputusan terkait pembiayaan kesehatan berdasarkan 
perencanaan penganggaran yang sesuai. Hasil peramalan digunakan sebagai dukungan dalam mencapai tujuan dan fungsi penganggaran sehingga tujuan organisasi dapat tercapai. Penganggaran merupakan rencana strategis untuk memastikan kuantitas yang menunjukkan sumber daya yang dibutuhkan dan dapat diantisipasi kembali selama jangka waktu tertentu. Penganggaran memastikan biaya yang ada cukup untuk menutup kegiatan operasional dalam jangka waktu tertentu. Selanjutnya berkaitan dengan perspektif jangka panjang, seperti pengembangan produk baru, yang meningkatkan ataupun menguatkan strategi terkait program hipertensi melalui kegiatan yang dapat sehingga berdampak pada penurunan biaya yang diperlukan. Fokus untuk menentukan sumber daya yang dibutuhkan pada proyek yang spesifik sehingga tidak terjadi kelebihan sumber daya. Terakhir sebagai akun pendapatan/pemasukan untuk memantau aliran dana yang digunakan sehingga semua sumber daya yang digunakan untuk kegiatan menjadi efektif dan efisien.

Penganggaran memiliki fungsi perencanaan untuk memastikan organisasi memiliki sumber daya yang tersedia untuk meraih tujuan. Kemudian menentukan pilihan atau opsi yang tersedia untuk mencapai tujuan berdasarkan misi yang terjabarkan dari tujuan serta memprediksi setiap opsi yang memilikii hasil memungkinkan termasuk biaya dan keuntungan dari setiap opsi. Fungsi selanjutnya adalah koordinasi yang menyatukan semua hal - anggaran individual dan divisi - dan menyeimbangkan serta mengkombinasikannya menjadi pembiayaan organisasi secara keseluruhan. Fungsi penganggaran lainnya adalah pengawasan yang digunakan untuk memonitor kemajuan kegiatan secara periodik. Kemajuan dari hal yang dilakukan dengan melihat hasil keputusan dan pelaksanaan dengan hasil penganggaran. Timbal baliknya, atau pengawasan dan evaluasi dari kemajuan menghasilkan tindakan korektif yang tepat waktu. Adanya peramalan menjadi bantuan informasi bagi organisasi dalam perencanaan anggaran agar menjamin ketersediaan sumber daya organisasi mencukupi untuk mencapai tujuan yang telah ditetapkan (13).

Peramalan kasus hipertensi untuk 36 bulan yang akan datang menunjukkan tren yang meningkat. Hal tersebut memungkinkan bahwa akan adanya peningkatan pembiayaan kasus hipertensi sehingga perlu adanya perhatian. Pembiayaan kasus hipertensi yang besar tentu merupakan nilai yang sangat besar untuk kasus penyakit di tingkat Puskesmas sehingga memerlukan penentuan perencanaan pengaggaran yang tepat untuk digunakan. Harapannya akan tercipta efektivitas dan efisiensi pelayanan kesehatan. Upaya mengendalikan kasus hipertensi dan pembiayaannya yang melalui peningkatan kegiatan pelayanan kesehatan masyarakat (efektivitas) dan pengawasan serta pengendalian (efisiensi).

\section{Simpulan dan Saran}

Adapun kesimpulan dari penelitian ini, sebagai berikut :

a. Jumlah kasus hipertensi di Kabupaten Jember berdasarkan hasil peramalan yaitu bulan Juli 2018 - Juni 2021 (36 bulan) memiliki tren meningkat dengan jumlah kasus banyak ditemukan pada perempuan daripada laki - laki namun memiliki risiko lebih besar terjadi pada laki-laki. Kasus hipertensi pada usia $\geq 45$ tahun memiliki tren meningkat dibandingkan dengan kasus hipertensi pada usia $\leq 44$ tahun. Peningkatan pelaporan kasus hipertensi disebabkan akibat adanya progam terkait hipertensi berupa skrining melalui posbindu, pusling, puskesmas, dan PIS-PK.

b. Pembiayaan kasus hipertensi di Kabupaten Jember berasal dari pemerintah (APBN, APBD, dan sumber lain yang sah dan tidak mengikat) dan BPJS Kesehatan (dana kapitasi dan non kapitasi). Pembiayaan kasus penyakit yang besar berkaitan dengan penganggaran sehingga hasil peramalan dapat membantu untuk menentukan perencanaan penganggaran yang efektif dan efisien dalam mengendalikan kasus hipertensi.

Adapun saran yang dapat diberikan peneliti dari hasil penelitian ini sebagai berikut :

a. Metode peramalan dapat digunakan sebagai alternatif untuk membantu menghadapi situasi kasus hipertensi berdasarkan pola tren yang diperlihatkan serta kebutuhan sumber daya kesehatan di masa yang akan datang.

b. Menghitung peramalan kasus penyakit menggunakan metode peramalan lain. Peramalan dapat dilakukan dengan data lain, yaitu berdasarkan kepesertaan JKN sehingga dapat memperlihatkan perbedaan pembiayaan suatu kasus penyakit berdasarkan status kepesertaan JKN.

c. Menghitung health expenditure dari kasus hipertensi untuk dapat memperkirakan kemungkinan biaya yang dibutuhkan kasus hipertensi di masa yang akan datang.

\section{Daftar Pustaka}

1. WHO. A global brief on Hyper - tension World Health Day 2013. World Health Organ; 2013 hlm. 1-40.

2. Lestaluhu F. Penerapan Metode Exponential Smoothing Untuk Meramalkan Jumlah Kasus Baru Hipertensi Di Kota Surabaya. Surabaya; 2018. 
3. Biro Komunikasi dan Pelayanan Masyarakat Sekretariat Jenderal Kementerian Kesehatan RI. Asosiasi Pemerintah Kabupaten Seluruh Indonesia Bersepakat Untuk Cegah Dan Kendalikan Penyakit Tidak Menular [Internet]. Depkes RI; 2016. Tersedia pada:

http://www.depkes.go.id/article/print/16080900002/asosiasi-pemerintah-kabupaten-seluruh-indonesiabersepakat-untuk-cegah-dan-kendalikan-penyakit-tidak.html

4. Badan Penelitian dan Pengembangan Kesehatan KKRI. Hasil Utama RISKESDAS 2018. 2018.

5. Situmorang J. Perencanaan Jangka Panjang di Perusahaan Multi Nasional. 2011;7(1):77-95.

6. Finira D, Yuliati L. Keluarga Dalam Pembelian Asuransi Jiwa. 2013;6(3):180-9.

7. Mubin L, Anggraeni W, Vinarti R. Prediksi Jumlah Kunjungan Pasien Rawat Jalan Menggunakan Metode Genetic Fuzzy Systems Studi Kasus : Rumah Sakit Usada Sidoarjo. Jurnal Teknik ITS. 2012;1(1):1-6.

8. Depkes RI. Sebagian Besar Penderita Hipertensi Tidak Menyadarinya [Internet]. Depkes RI; Tersedia pada: http://www.depkes.go.id/article/view/17051800002/sebagian-besar-penderita-hipertensi-tidakmenyadarinya

9. Kemenkes RI. Mencegah dan Mengontrol Hipertensi [Internet]. Kemenkes RI; 2014. Tersedia pada: https://doi.org/10.1177/109019817400200403

10. Kusumawaty J, Hidayat N, Ginanjar E. Hubungan Jenis Kelamin dengan Intensitas Hipertensi pada Lansia di Wilayah Kerja Puskesmas Lakbok Kabupaten Ciamis. 2016;16(2):46-51.

11. Seke P, Bidjuni H, Lolong J. Hubungan Kejadian Stres Dengan Penyakit Hipertensi Pada Lansia Di Balai Penyantunan Lanjut Usia Senjah Cerah Kecamatan Mapanget Kota Manado. e-journal Keperawatan. 2016;4:1-5.

12. Azwar A. Pengantar Administrasi Kesehatan. 3 ed. Jakarta: B. Aksara; 1996.

13. Berman K, Knight J. Financial Intelligence: A Manager's Guide to Knowing What the Number Really Mean. Boston: Harvard Press; 2013. 